\title{
High Estradiol Levels During Postmenopause - Pitfalls in Laboratory Analysis
}

\author{
Hohe Östriolspiegel in der Postmenopause - Fallstricke der Laboranalytik
}

Authors

Affiliation
I. Mebes, M. Graf, M. Kellner, C. Keck, S. E. Segerer

Endokrinologikum Hamburg, Zentrum für Hormon- und Stoffwechselerkrankungen, Reproduktionsmedizin und Pränatale Medizin, Hamburg

Key words
menopause
estradiol
irregular antibodies
cross-reaction
Schlüsselwörter
Hormone
Östrogen
Postmenopause

received 25.3.2015

revised 12.6.2015

accepted 12.6.2015

\section{Bibliography}

Dol http://dx.doi.org/

10.1055/s-0035-1557815

Geburtsh Frauenheilk 2015; 75 :

941-944 ๑ Georg Thieme

Verlag KG Stuttgart · New York .

ISSN 0016-5751

\section{Correspondence}

\section{S. E. Segerer}

Endokrinologikum Hamburg

Zentrum für Hormon- und

Stoffwechselerkrankungen,

Reproduktionsmedizin

und Pränatale Medizin

Lornsenstraße 4-6

22767 Hamburg

segerer.sabine@

googlemail.com

\section{Abstract \\ $\nabla$}

A 54-year-old woman was admitted with a result of high serum estradiol levels (> $4300 \mathrm{pg} / \mathrm{ml}$ ) and typical postmenopausal symptoms. She had a history of an adnexectomy (normal histopathology) due to the elevated estradiol levels. After surgery, estradiol levels were as high as before. Analyzing the anti-mullerian hormone (AMH), inhibin $\mathrm{B}$, DHEA-S and estrone, typical postmenopausal levels were found. Serum estradiol levels were controlled several times with rabbit-derived polyclonal as well as monoclonal antibodies to optimize the selectivity of the test system. Secondary, a radioimmunoassay was performed to exclude interferences of the detection system where lower, but still elevated estradiol levels ( $186 \mathrm{pg} /$ $\mathrm{ml}$ ) were found. Hypothesizing that our patient underwent a cross reaction with irregular antibodies, a control was done using sheep-derived antibodies, which proved a postmenopausal hormone level (estradiol level $<5 \mathrm{pg} / \mathrm{ml}$ ). This result was confirmed using a fluorescence enzyme immunoassay (FEIA) revealing high levels of irregular antibodies ( $>200 \mathrm{mg} / \mathrm{l}$; reference $<30 \mathrm{mg} / \mathrm{l}$ ). This case depicts the pitfalls of estradiol measurement detecting false elevated estradiol levels in a postmenopausal woman.

\section{Introduction \\ $\nabla$}

Due to the depletion of primordial follicles, ovarian estradiol secretion ceases at menopause and is followed by very low levels of circulating estradiol generating the typical menopausal symptoms.

\section{Zusammenfassung \\ $\nabla$}

Eine 54-jährige Patientin $(167 \mathrm{~cm}, 60 \mathrm{~kg})$ stellte sich mit klimakterischer Beschwerdesymptomatik (Hitzewallungen, Schlafstörungen) bei der behandelnden Gynäkologin vor. Im Rahmen der Diagnostik erfolgte eine Laborkontrolle, die einen deutlich erhöhten Estradiolwert ( $>4300$ pg/ml) zeigte. Da eine Estradiolproduktion im Rahmen einer Neoplasie vermutet wurde, wurde die Patientin zur operativen Abklärung in ein peripheres Krankenhaus eingewiesen und erhielt eine beidseitige Adnexektomie mit nachfolgend unauffälligem histopathologischen Ergebnis. In der postoperativen Kontrolle zeigte sich der Estradiolwert erneut deutlich erhöht. Die übrigen Hormonwerte entsprachen einem unauffälligen postmenopausalen Befund. Zur Optimierung der Sensitivität des Labortests wurde zunächst ein monoklonaler Antikörper eingesetzt. Auch eine Analyse mittels Radioimmunoassay ergab bereits niedrigere, dennoch weiterhin erhöhte Werte (186 pg/ml). In der Annahme, dass möglicherweise eine Kreuzreaktivität gegen irreguläre Antikörper vorliegen könnte, wurde eine Kontrolle mit Schafsantikörpern durchgeführt, die nun einen typisch postmenopausalen Estradiolspiegel ergaben $(<5 \mathrm{pg} / \mathrm{ml})$. Ein Fluoreszenz-Enzym-Immunoassay konnte in der Tat das Vorliegen irregulärer Antikörper bestätigen (> $200 \mathrm{mg} / \mathrm{l}$; Referenz $<30 \mathrm{mg} / \mathrm{l}$ ). In diesem Fallbericht werden somit mögliche Fehlerquellen der Estradiolmessung bei postmenopausalen Frauen aufgezeigt.

However, the arrest of ovarian estradiol secretion does not induce an overall loss of estrogen production: After menopause, sex steroids continue to be synthesized in peripheral tissues depending on steroid forming enzymes specific for each tissue [1]. In contrast to the ovarian estradiol secre- 


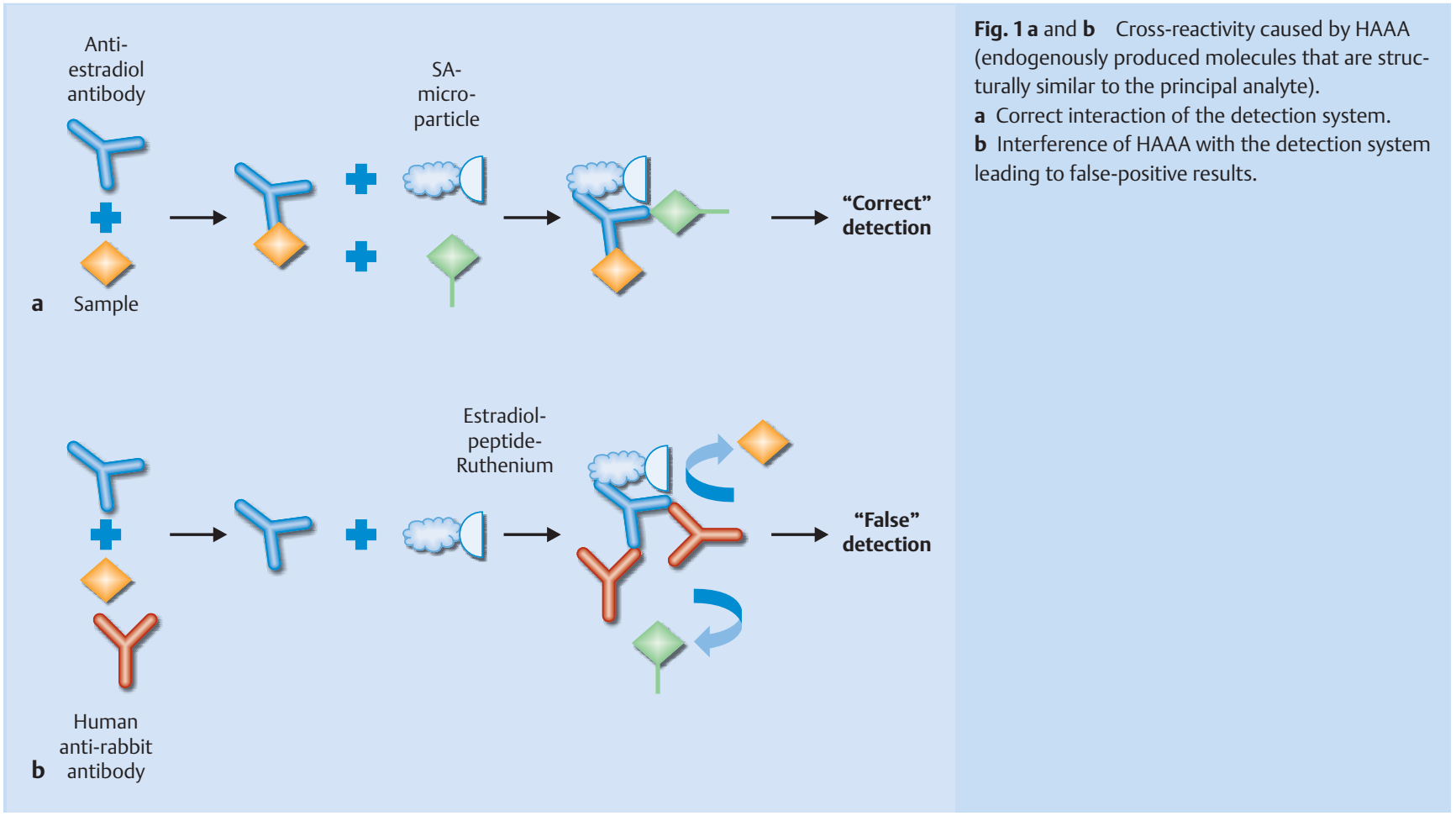

tion, peripheral produced estrogens are inactivated intracellularly without significant release to the blood circulation.

One of the common and stressful symptoms of menopause are hot flushes (HF), which occur in $>75 \%$ of menopausal women [2]. The episodic sensations of heat, intense sweating and flushing can recur with varying frequency and intensity [3]. Likewise, the age at onset of HF is varying from woman to woman. Even though the pathophysiology of HF is not entirely understood, several authors propose that HF are due to a changed thermoregulation set point of the hypothalamus evoked by the lowered estrogen levels during menopause $[3,4]$. Thereby, estrogens seem to interact with several neurotransmitters like norepinephrine, serotonin and endogenous opioids [5,6]. Vasomotor symptoms can also occur in women with abrupt drop in sex steroid hormones such as after removal of the ovaries of premenopausal women or in breast cancer patients with chemically induced menopause [3]. However, estradiol levels do neither explain the presence of HF nor correlate with their frequency and intensity $[3,7]$. Thus, measurement of estradiol levels during menopause rarely reveals clinical benefits. Even after an adequate restoration of estradiol levels by hormone replacement therapies, women can still experience vasomotor symptoms.

Rarely, high levels of circulating estradiol have been reported in postmenopausal women so far and have often been attributed to estradiol-producing neoplasia.

In this case report, we describe a postmenopausal woman with persisting postmenopausal symptoms in whom high estradiol levels have been measured.

\section{Case Report}

We report the case of a 54-year-old woman of normal weight $(167 \mathrm{~cm}, 60 \mathrm{~kg})$, who presented with extremely high serum levels of estradiol $(>4300 \mathrm{pg} / \mathrm{ml})$. Apart from the typical vasomotor symptoms, she did not have any complaints nor an aberrant physical examination.The blood sample was initiated by her local gynecologist just to confirm her menopausal status. Due to the highly elevated estradiol level, she had been sent to a local hospital for a bilateral adnexectomy expecting an estradiol producing ovarian neoplasia. The ovarian histology was completely unsuspicious. After surgery, the estradiol levels did not change at all and the patient was sent to our institution for further analysis. Clinically, the patient complained of the typical symptoms of hormone deficiency like hot flushes, night sweats, vaginal dryness, sexual dysfunction and poor performance. Her last menstruation had occurred one year ago. Any hormone, drug or alcohol consumption was denied. Physical examination showed a vaginal atrophy and a postmenopausal vaginal smear. Hormonal analysis was repeated at our institution and revealed a high serum estradiol level above range $(>4300 \mathrm{pg} / \mathrm{ml}$ ). The first test (immunoassay) was done using a biotinylated rabbit-derived polyclonal antibody for estradiol. However, testing other sex steroids and glycoprotein hormones indicating an ovarian or extra-ovarian production, typical blood levels of a postmenopausal woman were found (estrone $13.4 \mathrm{ng} / \mathrm{l}$; progesterone $<0.10 \mathrm{ng} / \mathrm{ml}$; testosterone < $0.03 \mathrm{ng} / \mathrm{ml}$; FSH $70.8 \mathrm{mIE} / \mathrm{ml}$, LH $30.5 \mathrm{mIE} / \mathrm{ml}$; inhibin $\mathrm{B}<10 \mathrm{ng} / \mathrm{l} ; \mathrm{AMH}<0.08 \mathrm{ng} / \mathrm{ml}$ ).

To increase the selectivity of the antibody-ligand reaction, first, an immunoassay with rabbit-derived monoclonal antibodies was performed. However, detecting still high estradiol levels, we changed the detection system to exclude interferences of the immunoassay label. Applying a radioimmunoassay, lower but still elevated estradiol levels $(186 \mathrm{pg} / \mathrm{ml})$ could be detected.

Another reason for false positive results are cross-reacting molecules which can be induced by structural similarities of the epitopes [8]. Hypothesizing a cross-reactivity with irregular antibodies, we changed the host and applied sheep-derived antibodies which revealed typical postmenopausal estradiol levels $(<5 \mathrm{pg} / \mathrm{ml})$. Our hypothesis of false positive results has been con- 
firmed using a fluorescence enzyme immunoassay (FEIA) with specific $\operatorname{IgG}$ antibodies against rabbit tissue. Here, a high level of anti-rabbit IgG antibodies could be detected ( $>200 \mathrm{mg} /$ l; reference $<30 \mathrm{mg} / \mathrm{l}$ ) indicating circulating specific anti-rabbit IgG antibodies in the patient.

Asking for her confined domestic circumstances, she reported about breeding rabbits.

\section{Discussion}

Clinical diagnostics require an accurate measurement of hormone levels. In postmenopausal women, even high sensitive methods like liquid chromatography-mass spectrometry (LC-MS) are performed to detect estradiol concentrations at low picomolar levels [9]. To date, a variety of immunoassays have been established, mostly monoclonal or polyclonal antibody assays [10]. However, applying automated immunoassays, non-specific results and method-specific bias have to be considered. Interferences can be induced by structural similarities of different epitopes (in the case of polyclonal primary antibodies), by unspecific binding of the detection system or when endogenously produced molecules exist that are structurally similar to the principal analyte ( Fig. 1).

In this case, we report a cross-reactivity caused by Human AntiAnimal Antibodies (HAAA). HAAA are immunoglobulins (Ig) which can be induced by longtime contact to animals. These HAAA are also known to induce a cross-reactivity within immunoassays $[11,12]$. Detecting false positive results, a cross-reactivity with the host serum can be assumed and should be excluded by changing the host. If the cross-reactivity is not found any more by changing the host, the presence of irregular antibodies can be assumed and can be confirmed by FEIA.

Apart from method-specific bias of the immunoassays elevated estradiol levels in postmenopausal women can be due to hormone and drug consumption. Rare cases of estrogen producing tumors like sex cord stromal tumors including granulosa cell tumors, thecoma and Sertoli stroma cell tumors are described. Thereof, the most common hormonally active are granulosa cell tumors. Granulosa cell tumors are potentially malignant sex cord stromal tumors of the ovary and account for $2 \%$ of all ovarian tumors. They can be divided into adult (95\%) and juvenile (5\%) types based on histological findings [13]. Due to their hormone production, most of them can be detected in an early stage. Germ cell tumors (ovarian carcinoid) as well as Brenner tumors are only rarely associated with endocrine manifestations [14-16]. Feminizing adrenal tumors are rare [17] and comprise adrenocortical adenoma and carcinoma which can lead to an increase of estradiol levels $[18,19]$. Several reports demonstrated the presence of high aromatase enzyme activity and an overexpression of CYP19 mRNA [20,21]. In adrenocortical adenoma, estradiol peaks could even be found at $120 \mathrm{pg} / \mathrm{ml}$ [22]. Apart from neoplasia, liver cirrhosis can provoke an increase in estradiol (up to $60 \mathrm{pg} / \mathrm{ml}$ ) [23, 24]. Finally, contamination of nutrition (e.g. Fusarium toxin-contaminated maize) can induce hyperestrogenism [25].

Generally, measurement of estradiol levels in postmenopausal women is not considered and rarely reveals clinical benefits. If clinical symptoms are not in line with the detected hormone levels, exclusion of method-specific bias or interferences of the test system should be considered. Otherwise misinterpretation of the results can lead to unnecessary interventions - as observed in our case.

\section{Authors' Roles}

\section{$\nabla$}

IM drafted the manuscript and performed the data collection. MK participated in the experimental concept and carried out the laboratory tests. MG revised the manuscript. CK participated in editorial support; SES participated in the design of the study and revised the article. All authors read and approved the final manuscript.

\section{Conflict of Interest}

\section{$\nabla$}

None.

\section{References}

1 Labrie F. All sex steroids are made intracellularly in peripheral tissues by the mechanisms of intracrinology after menopause. J Steroid Biochem Mol Biol 2015; 145: 133-138

2 Pachman DR, Jones JM, Loprinzi CL. Management of menopause-associated vasomotor symptoms: current treatment options, challenges and future directions. Int J Womens Health 2010; 2: 123-135

3 Kronenberg $F$. Menopausal hot flashes: a review of physiology and biosociocultural perspective on methods of assessment. J Nutr 2010; 140: 1380S-1385S

4 Adelson KB, Loprinzi CL, Hershman DL. Treatment of hot flushes in breast and prostate cancer. Expert Opin Pharmacother 2005; 6: 10951106

5 Berendsen $\mathrm{HH}$. The role of serotonin in hot flushes. Maturitas 2000; 36 : 155-164

6 Casper RF, Yen SS. Neuroendocrinology of menopausal flushes: an hypothesis of flush mechanism. Clin Endocrinol (Oxf) 1985; 22: 293-312

7 Overlie I, Moen MH, Holte A et al. Androgens and estrogens in relation to hot flushes during the menopausal transition. Maturitas 2002; 41: 69-77

8 Miller JJ, Valdes $R \mathrm{jr}$. Approaches to minimizing interference by crossreacting molecules in immunoassays. Clin Chem 1991; 37: 144-153

9 Keski-Rahkonen P, Huhtinen K, Desai R et al. LC-MS analysis of estradiol in human serum and endometrial tissue: comparison of electrospray ionization, atmospheric pressure chemical ionization and atmospheric pressure photoionization. J Mass Spectrom 2013; 48: 1050-1058

10 Abraham GE. Solid-phase radioimmunoassay of estradiol-17 beta. J Clin Endocrinol Metab 1969; 29: 866-870

11 Gorovits B, McNally J, Fiorotti $C$ et al. Protein-based matrix interferences in ligand-binding assays. Bioanalysis 2014; 6: 1131-1140

12 Kragstrup TW, Vorup-Jensen T, Deleuran B et al. A simple set of validation steps identifies and removes false results in a sandwich enzyme-linked immunosorbent assay caused by anti-animal IgG antibodies in plasma from arthritis patients. Springerplus 2013; 2: 263

13 Geetha P, Nair MK. Granulosa cell tumours of the ovary. Aust N Z J Obstet Gynaecol 2010; 50: 216-220

14 Guo L, Yang X, Zhu H et al. Sertoli-Leydig cell tumor presenting hyperestrogenism in a postmenopausal woman: a case report and review of the literature. Taiwan J Obstet Gynecol 2012; 51: 620-624

15 Rey RA, Lhomme C, Marcillac I et al. Antimullerian hormone as a serum marker of granulosa cell tumorsof the ovary: comparative study with serum alpha-inhibin and estradiol. Am J Obstet Gynecol 1996; 174: 958-965

16 Joh K, Aizawa S, Ohkawa K et al. Case report of a malignant Brenner tumor with hyperestrogenism. Pathol Int 1995; 45: 75-84

17 Bertagna C, Orth DN. Clinical and laboratory findings and results of therapy in 58 patients with adrenocortical tumors admitted to a single medical center (1951 to 1978). Am J Med 1981; 71: 855-875

18 Sharma DC, Raheja MC, Dorfman RI et al. Studies on a feminizing human adrenal tumour. II. Biosynthesis in vitro of steroid hormones from testosterone-4-14C and androst-4-ene-3,17-dione-4-14C by a feminizing adrenal tumour. Acta Endocrinol (Copenh) 1965; 50: 439-451

19 deAsis DN jr., Samaan NA. Feminizing adrenocortical carcinoma with Cushing's syndrome and pseudohyperparathyroidism. Arch Intern Med 1978; 138: 301-303

20 Goto T, Murakami O, Sato $F$ et al. Oestrogen producing adrenocortical adenoma: clinical, biochemical and immunohistochemical studies. Clin Endocrinol (Oxf) 1996; 45: 643-648 
21 Young J, Bulun SE, Agarwal Vet al. Aromatase expression in a feminizing adrenocortical tumor. J Clin Endocrinol Metab 1996; 81: 3173-3176

22 Bouraima H, Lireux B, Mittre H et al. Major hyperestrogenism in a feminizing adrenocortical adenoma despite a moderate overexpression of the aromatase enzyme. Eur J Endocrinol 2003; 148: 457-461

23 Van Thiel DH, Gavaler JS, Slone FL et al. Is feminization in alcoholic men due in part to portal hypertension: a rat model. Gastroenterology 1980; 78: 81-91
24 Longcope C, Pratt JH, Schneider S et al. Estrogen and androgen dynamics in liver disease. J Endocrinol Invest 1984; 7: 629-634

25 Rempe I, Brezina U, Kersten $S$ et al. Effects of a Fusarium toxin-contaminated maize treated with sodium metabisulphite, methylamine and calcium hydroxide in diets for female piglets. Arch Anim Nutr 2013; 67: $314-329$ 